\title{
UJI DAYA HAMBAT EKSTRAK ETANOL BAWANG DAYAK (Eleutherine bulbosa (Mill.) Urb.) TERHADAP BAKTERI Staphylococcus aureus
}

\author{
Susi Novaryatiin ${ }^{1}$, Ahmad Ramli ${ }^{2}$, Syahrida Dian Ardhany ${ }^{1}$ \\ 1Dosen Pengajar Program Studi DIII Farmasi, Fakultas IImu Kesehatan, Universitas \\ Muhammadiyah Palangkaraya \\ ${ }^{2}$ Mahasiswa Program Studi DIII Farmasi, Fakultas IImu Kesehatan, Universitas \\ Muhammadiyah Palangkaraya \\ e-mail : susi novaryatiin@yahoo.com
}

\begin{abstract}
ABSTRAK
Bawang Dayak merupakan tanaman khas Kalimantan Tengah. Tanaman ini sudah secara turun temurun dipergunakan masyarakat Dayak sebagai obat tradisional. Secara empiris, umbi Bawang Dayak dikenal memiliki khasiat untuk mengatasi bisul atau penyakit kulit. Tujuan dalam penelitian ini adalah untuk mengetahui kemampuan daya hambat ekstrak etanol Bawang Dayak dalam menghambat bakteri Staphylococcus aureus dan untuk mengetahui efektivitas daya hambat ekstrak etanol Bawang Dayak serta konsentrasi yang mampu menghambat pertumbuhan bakteri Staphylococcus aureus. Penelitian ini dilakukan dengan cara pengujian aktivitas antibakteri ekstrak etanol Bawang Dayak pada konsentrasi 1\%, 5\%, 10\%, dan 15\% dengan metode Disc Diffusion (kirby-bauer) yaitu dengan menggunakan kertas cakram (disc). Hasil penelitian menunjukkan ekstrak etanol Bawang Dayak mampu menghambat pertumbuhan bakteri Staphylococcus aureus dan efektif menghambat pertumbuhan bakteri Staphylococcusaureus pada konsentrasi 1\%, 5\%, 10\%, dan 15\% dengan zona hambat secara berturut-turut yaitu 14,3 $\pm 2,5 \mathrm{~mm} ; 16,6 \pm 1,7 \mathrm{~mm} ; 16,2 \pm 2,0 \mathrm{~mm}$; dan 18,0 $\pm 1,7 \mathrm{~mm}$.
\end{abstract}

Kata Kunci: Bawang Dayak, Eleutherine bulbosa (Mill.) Urb., aktivitas antibakteri, Staphylococcus aureus

\begin{abstract}
Bawang Dayak is a typical plant of Central Kalimantan. This plant has been traditionally used by Dayak community as a traditional medicine. Empirically, Bawang Dayak bulbs are known to have efficacy to overcome ulcers or skin diseases. The objective of this research were to determine the inhibition ability of ethanolic extract of Bawang Dayak against Staphylococcus aureus bacteria, and to know the inhibition effectiveness of ethanolic extract of Bawang Dayak as well as concentrations that capable of inhibiting the growth of Staphylococcus aureus bacteria. This research was conducted by testing the antibacterial activity of ethanolic extract of Bawang Dayak at concentration of $1 \%, 5 \%, 10 \%$, and $15 \%$ with Disc Diffusion method (KirbyBauer) by using disc paper.The results showed that ethanolic extract of Bawang Dayak was able to inhibit the growth of Staphylococcus aureus bacteria and effectively inhibits growth of Staphylococcus aureus bacteria at concentrations 1\%, 5\%, 10\% and $15 \%$ with inhibition zone were $14,3 \pm 2,5 \mathrm{~mm} ; 16,6 \pm 1,7 \mathrm{~mm} ; 16,2 \pm 2,0 \mathrm{~mm}$; dan $18,0 \pm 1,7 \mathrm{~mm}$, respectively
\end{abstract}

Keywords:Bawang Dayak, Eleutherine bulbosa (Mill.) Urb., antibacterial activity, Staphylococcus aureus 


\section{PENDAHULUAN}

Pemanfaatan tumbuhan sebagai obat tradisional bukanlah hal yang baru, dan telah dikenal masyarakat secara luas sejak zaman dahulu. Saat ini penggunaan obatobatan berasal dari tanaman banyak diminati, meskipun telah banyak beredar obat jadi yang merupakan senyawa sintesis. Hal ini dibuktikan dengan adanya kecenderungan masyarakat global untuk kembali ke alam (back to nature) dalam bidang penyediaan obat-obatan ${ }^{1}$.

Salah satu tumbuhan khas Kalimantan yang berkhasiat sebagai obat tradisional adalah Bawang Dayak. Bawang Dayak (Eleutherine bulbosa (Mill.) Urb.) termasuk tumbuhan yang sangat mudah ditemukan di daerah Kalimantan. Tumbuhan ini banyak sekali terdapat di lingkungan tempat tinggal masyarakat suku Dayak². Masyarakat suku Dayak percaya bahwa dengan mengkonsumsi Bawang Dayak dapat mengobati penyakit infeksi kulit apabila sistem tubuh rendah ${ }^{3}$.

Secara empiris, umbi Bawang Dayak dikenal memiliki khasiat untuk mengatasi bisul atau penyakit kulit ${ }^{4}$ Cara penggunaannya yaitu dengan menempelkan parutan umbi Bawang Dayak pada daerah yang luka ${ }^{5}$. Sedangkan berdasarkan observasi yang dilakukan, menurut masyarakat Dayak rebusan Bawang Dayak mampu mengatasi penyakit kulit dan beberapa penyakit lainnya. Tumbuhan Bawang Dayak diketahui memiliki kandungan senyawa kimia antara lain, alkaloid, flavonoid, kuinon, polifenol, saponin, steroid, monoterpenoid, dan tanin ${ }^{3}$.

Luka adalah kerusakan pada struktur anatomi kulit yang menyebabkan terjadinya gangguan kulit. Infeksi pada luka dapat disebabkan oleh beberapa mikroorganisme seperti bakteri, parasit, virus, dan jamur. Salah satu bakteri yang menyebabkan infeksi pada kulit adalah bakteri Staphylococcus aureus ${ }^{6}$.

Penelitian ini bertujuanuntuk mengetahui kemampuan daya hambat ekstrak etanol Bawang Dayak terhadap bakteri Staphylococcus aureus, dan untuk mengetahui efektivitas daya hambat ekstrak etanol Bawang Dayak serta konsentrasi yang mampu menghambat pertumbuhan bakteri Staphylococcusaureus.

\section{METODE PENELITIAN}

Rancangan Penelitian

Penelitian ini dilakukan di Laboratorium Farmakognosi dan Laboratorium Mikrobiologi Fakultas IImu Kesehatan Universitas Muhammadiyah Palangkaraya. Penelitian dilaksanakan selama 6 (enam) bulan. Kegiatan penelitian yang dilakukan adalah pengambilan sampel, pembuatan simplisia, pembuatan ekstrak, penanaman bakteri, dan uji daya hambat. 


\section{Sampel Penelitian}

Sampel penelitianadalah tumbuhan Bawang Dayak budidaya yang tumbuh di Jl. Cendrawasih II UPT Km.38, Kelurahan Sei Gohong, Kecamatan Bukit Batu, Kota Palangka Raya, Provinsi Kalimantan Tengah. Bagian yang digunakan adalah umbi yang masih segar.

\section{Pembuatan Simplisia}

Dilakukan sortasi basah pada umbi Bawang Dayak, lalu umbi diris, dan dijemur. Setelah kering simplisia disortasi kembali dan dihaluskan hingga menjadi serbuk ${ }^{7}$.

\section{Pembuatan Ekstrak}

Pembuatan ekstrak umbi Bawang Dayak dilakukan dengan metode sokhletasi.Keuntungan dari metode ini yaitu bukan banyak bagian dari pelarut hangat yang melewati sampel, hanya satu batch pelarut yang didaur ulang ${ }^{8}$. Penggunaan pelarut etanol 96\% karena etanol merupakan pelarut universal yang mampu melarutkan hampir seluruh jenis metabolit sekunder

yang mempunyai berat molekul rendah seperti flavonoid dan saponin, tidak bersifat racun, serta aman untuk digunakan ${ }^{9}$. Dilakukan penimbangan ekstrak kental yang didapat. Ekstrak yang diperoleh lalu dibuat dalam berbagai variasi konsentrasi yaitu $1 \%, 5 \%, 10 \%$, dan $15 \%$.

\section{Penanaman Bakteri}

Bakteri Staphylococcus aureus ditanam pada media Brain Heart Infusion (BHI) pada suhu $37 \stackrel{\circ}{ } \mathrm{C}$ selama 24 jam, lalu ditumbuhkan pada media Blood Agar Plate (BAP) pada suhu $37^{\circ} \mathrm{C}$ selama 24 jam 1 .

\section{Uji Daya Hambat}

Uji daya hambat dilakukan menggunakan metode difusi (Kirby-Bauer), dimana disc direndam dalam variasi konsentrasi ekstrak etanol umbi Bawang Dayak $1 \%, 5 \%, 10 \%$, dan $15 \%$. Standar McFarland 0,5 disiapkan, dan $10 \mathrm{ml}$ dimasukkan ke dalam tabung steril. Suspensi bakteri dibuat dengan mengambil koloni bakteri, diencerkan dalam $\mathrm{NaCl}$ steril, dan kekeruhan disesuaikan dengan standar McFarland 0,5. Suspensi bakteri diambil dan di-streak pada media Mueller Hinton Agar (MHA) dengan menggunakan lidi kapas steril. Kemudian semua disc yang telah direndam dalam ekstrak etanol umbi Bawang Dayakditanam pada media MHA. Antibiotik klindamisin digunakan sebagai kontrol positif dengan variasi konsentrasi $1 \%, 5 \%$, 10\%, dan $15 \%$. Disc yang telah direndam dalam klindamisin juga ditanam di media MHA. Inkubasi dilakukan pada suhu $37^{\circ} \mathrm{C}$ selama 24 jam. Zona hambat diukur menggunakan jangka sorong. Dilakukan pengulangan sebanyak tiga kali (triplo) untuk masing-masing ekstrak dan kontrol positif. 


\section{Teknik Analisis Data}

Analisis data dilakukan dengan menghitung zona hambat ekstrak etanol umbi Bawang Dayak terhadap bakteri Staphylococcus aureus. Hasil disajikan dalam bentuk tabel dan foto,disertai dengan perbandingan antara hasil yang diperoleh dengan standar yang telah ditetapkan oleh $\mathrm{CLSI}^{10}$.

\section{HASIL DAN PEMBAHASAN}

\section{Perhitungan Rendemen Ekstrak}

$$
\begin{aligned}
\text { Rendemen } & =\frac{\text { Berat ekstrak kental }}{\text { Berat simplisia }} \times 100 \% \\
& =\frac{33,5 \text { gram }}{504,4343 \text { gram }} \times 100 \% \\
= & 0,0665 \times 100 \% \\
= & 6,65 \%
\end{aligned}
$$

Jumlah total ekstrak kental yang diperoleh adalah sebanyak $33,5 \mathrm{gr}$ dan rendemen yang didapatkan adalah 6,65 \% (Gambar 1).

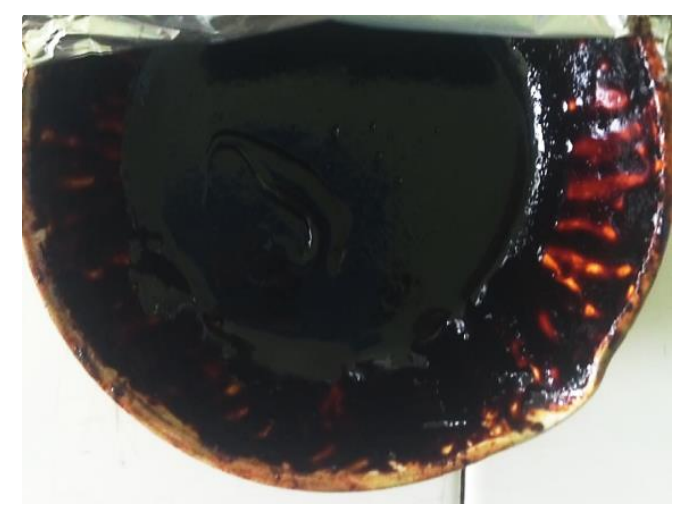

Gambar 1. Ekstrak kental umbi Bawang Dayak 


\section{Uji Daya Hambat}

Hasil uji daya hambat ekstrak etanol umbi Bawang Dayak dapat dilihat pada Tabel 1 berikut ini.

Tabel 1. Hasil Pengukuran Zona Hambat Ekstrak Etanol Daun Umbi Bawang Dayak Dibandingkan dengan CLSI

\begin{tabular}{cccc}
\hline Uji & $\begin{array}{c}\text { Konsentrasi } \\
(\%)\end{array}$ & $\begin{array}{c}\text { Zona Hambat } \pm \\
\text { SD }(\mathbf{m m})\end{array}$ & $\begin{array}{c}\text { Interpretasi } \\
\text { Daya Hambat }\end{array}$ \\
\hline Kontrol Positif & 1 & $48,3 \pm 1,3$ & Susceptible \\
Klindamisin & 5 & $46,2 \pm 2,1$ & Susceptible \\
& 10 & $48,8 \pm 2,6$ & Susceptible \\
& 15 & $49,8 \pm 1,2$ & Susceptible \\
\hline Ekstrak Etanol Umbi & 1 & $14,3 \pm 2,5$ & Resistant \\
Bawang Dayak & 5 & $16,6 \pm 1,7$ & Intermediate \\
& 10 & $16,2 \pm 2,0$ & Intermediate \\
& 15 & $18,0 \pm 1,7$ & Intermediate
\end{tabular}

Keterangan :

* Interpretasi Daya Hambat (CLSI, 2013),

$$
\begin{aligned}
& \leq 15 \mathrm{~mm}=\text { Resistant } \\
& 16-18 \mathrm{~mm}=\text { Intermediate } \\
& \geq 19 \mathrm{~mm}=\text { Susceptible }
\end{aligned}
$$

Pada penelitian ini klindamisin digunakan sebagai kontrol positif. Klindamisin mempunyai mekanisme membunuh bakteri dengan cara mencegah sintesis protein dari bakteri. Klindamisin merupakan antimikroba yang bersifat bakteriostatik maupun bakterisida ${ }^{11}$. Berdasarkan spektrumnya antibiotik ini termasuk dalam golongan antibiotik spektrum sempit yang hanya bekerja pada bakteri gram positif saja ${ }^{12}$.
Zona hambat yang dihasilkan oleh klindamisin pada konsentrasi $1 \%, 5 \%, 10 \%$, dan $15 \%$ terhadap Staphylococcus aureus secara berturut-turut adalah 48,3 $\pm 1,3 \mathrm{~mm}$;

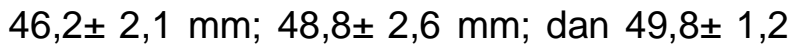
mm (Tabel 1, Gambar 2). Berdasarkan CLSI, zona hambat klindamisin yang diujikan pada semua konsentrasi dikategorikan susceptible. 


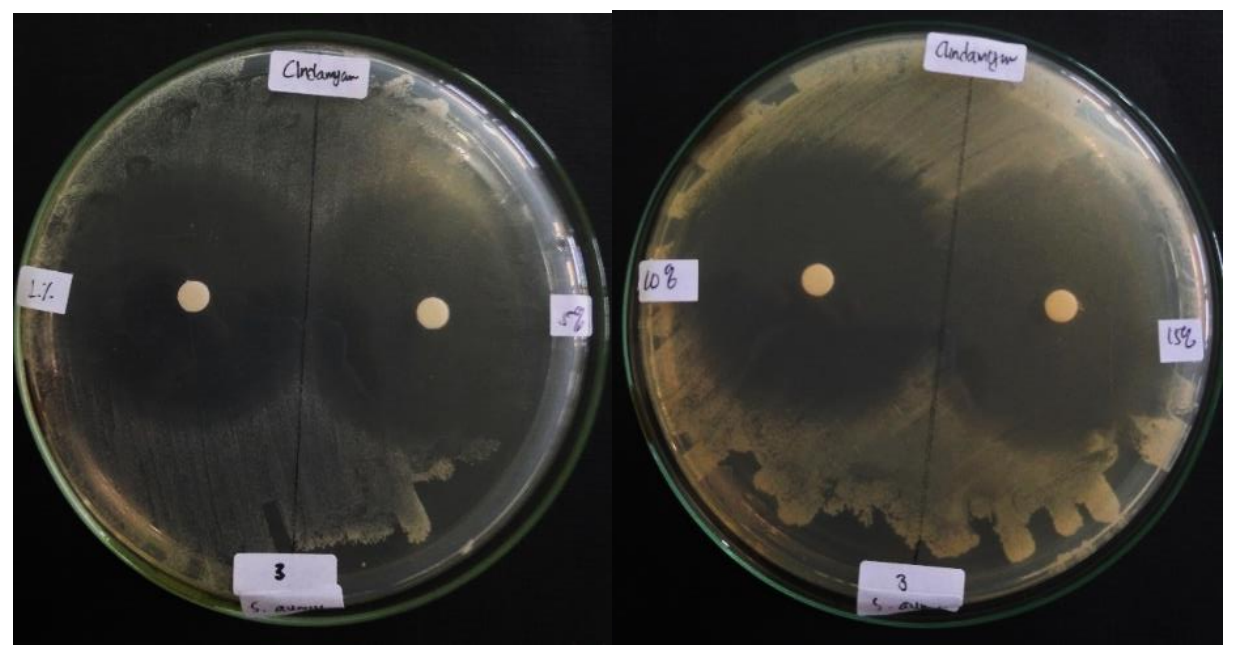

Gambar 2. Daya hambat antibiotik klindamisin terhadap bakteri Staphylococcus aureus

Hasil pengamatan pada uji daya mm; 16,2 $\pm 2,0 \mathrm{~mm}$; dan 18,0 $\pm 1,7 \mathrm{~mm}$ (Tabel hambat ekstrak etanol Bawang Dayak 1, Gambar 3).

terhadap bakteri Staphylococcous aureus Jika dibandingkan dengan hasil yang dilakukan sebanyak 3 kali pengulangan, penelitian sebelumnya, zona hambat yang menunjukkan nilai diameter zona hambat dihasilkan pada penelitian ini sedikit lebih yang berurutan sesuai dengan konsentrasi kecil dibandingkan dengan zona hambat yang yang digunakan. Standar deviasi (SD) diukur dihasilkan oleh ekstrak etanol Bawang Dayak untuk mengetahui seberapa baik mean (rata- terhadap bakteriStaphylococcus epidermidis. rata) mewakili data. Semakin kecil SD Pada penelitian tersebut,diperoleh rata-rata mengindikasikan data dekat dengan mean. zona hambat pada konsentrasi $1 \%, 5 \%, 10 \%$, Semakin besar SD mengindikasikan data dan $15 \%$ secara berturut-turut sebesar jauh dari mean. Rata-rata zona hambat 16,9 $\pm 3,6 \mathrm{~mm} ; 17,6 \pm 1,8 \mathrm{~mm} ; 18,6 \pm 0,0 \mathrm{~mm}$; ekstrak etanol Bawang Dayak pada dan 18,4 $\pm 0,4 \mathrm{~mm}^{1}$. konsentrasi $1 \%, 5 \%, 10 \%$, dan $15 \%$ secara berturut-turut yaitu $14,3 \pm 2,5 \mathrm{~mm} ; 16,6 \pm 1,7$ 


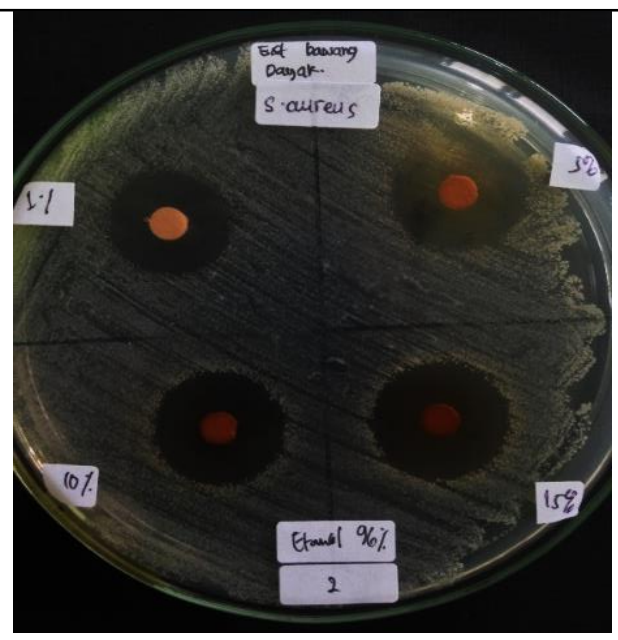

Gambar 3. Daya hambat ekstrak etanol umbi Bawang Dayak terhadap bakteri Staphylococcus aureus

Semakin tinggi konsentrasi dari ekstrak etanol Bawang Dayak, maka semakin besar daya hambatnya. Berdasarkan CLSI (2013) hasil zona hambat pada ekstrak etanol Bawang Dayak terhadap bakteri Staphylococcous aureus pada konsentrasi $1 \%$ dikategorikan resistant, sedangkan pada konsentrasi $5 \%$, $10 \%$, dan $15 \%$ bersifat intermediate [10]. Sedangkan jika mengacu pada kategori penghambatan antimikroba berdasarkan zona hambat menurut Pan et al (2009), hasil zona hambat pada ekstrak etanol Bawang Dayak terhadap bakteri Staphylococcous aureus pada semua konsentrasi menunjukkan respon hambatan pertumbuhan yangtermasuk dalam kategori high $^{13}$.

Terbentuknya zona hambat di sekitar cakram menunjukkan adanya aktivitas antibakteridari Bawang Dayak. Semakin luas zona bening yang ada di sekitar cakram, maka semakin banyak jumlah bakteri yang mati. Aktivitas antibakteri Bawang Dayak ini disebabkan karena adanya kandungan senyawa kimia atau metabolit sekunder yang dapat menghambat pertumbuhan bakteri Staphylococcus aureus yaitu alkaloid, flavonoid, tanin, dan saponin yang ada di dalam Bawang Dayak ${ }^{3}$.

$$
\text { Alkaloid diketahui mampu }
$$
menghambat pertumbuhan bakteri dengan mengganggu komponen penyusun peptidoglikan pada sel bakteri sehingga lapisan dinding sel tidak terbentuk secara utuh dan menyebabkan kematian sel bakteri. Alkaloid merupakan interkelator DNA yang mampu menghambat enzim topoisomerase sel bakteri ${ }^{14}$. Sedangkan mekanisme antibakteri flavonoid yaitu dengan merusak permeabilitas dinding 
sel bakteri, mikrosom, dan lisosom sebagai hasil interaksi antara flavonoid dengan DNA bakteri melalui penghambatan yang mengakibatkan penggabungan rantai glikan tidak terhubung silang ke dalam peptidoglikan membran sel sehingga menjadi satu struktur yang lemah ${ }^{15,16}$.

Aktivitas antibakteri $\operatorname{tanin}$ berhubungan dengan kemampuannya untuk menginaktifkan adhesin sel mikroba, menginaktifkan enzim, dan mengganggu transport protein pada lapisan dalam sel. Tanin juga mempunyai target pada polipeptida dinding sel sehingga pembentukan dinding sel menjadi kurang sempurna. Hal ini menyebabkan sel bakteri menjadi lisis karena tekanan osmotik maupun fisik sehingga sel bakteri akan mati ${ }^{17}$. Mekanisme saponin sebagai antibakteri adalah dengan cara merusak membran sel bakteri akibat terjadinya peningkatan permeabilitas membran oleh karena saponin yang berinteraksi dengan dinding sel bakteri ${ }^{16}$.

\section{KESIMPULAN}

Kesimpulan yang didapat dari penelitian ini yaitu ekstrak etanol umbi Bawang Dayak mampu menghambat pertumbuhan bakteri Staphylococcus aureuspada konsentrasi yang diujikan $1 \%$, $5 \%, 10 \%$, dan $15 \%$ dengan zona hambat berturut-turut $14,3 \pm 2,5 \mathrm{~mm} ; 16,6 \pm 1,7 \mathrm{~mm}$; $16,2 \pm 2,0 \mathrm{~mm}$; dan 18,0 $\pm 1,7 \mathrm{~mm}$. Namun zona hambat yang dihasilkan jauh lebih kecil jika dibandingkan dengan zona hambat yang dihasilkan kontrol positif klindamisin terhadap bakteri Staphylococcus aureus. Aktivitas antibakteri yang dimiliki umbi Bawang Dayak diduga karena adanya kandungan alkaloid, flavonoid, tanin, dan saponin. Semua senyawa kimia tersebut diketahui memiliki aktivitas antibakteri dengan mekanisme yang berbeda-beda.

\section{DAFTAR PUSTAKA}

1. Novaryatiin, S., Pratiwi, A.M., Ardhany, S.A. 2018. Uji Daya Hambat Ekstrak Etanol Bawang Dayak (Eleutherine bulbosa (Mill.) Urb.) Terhadap Bakteri Staphylococcus epidrmidis. Jurnal Anterior, 18(1):92-97.

2. Takoy, D.M., Linda, R., Lovadi, I. 2013. Tumbuhan Berkhasiat Obat Suku Dayak Seberuang di Kawasan Hutan Desa Ensabang Kecamatan Sepauk Kabupaten

Sintang.Protobiont:JurnalElektronik Biologi,2(3):122-128.

3. Puspadewi, R., Adirestuti, P., Menawati, R. 2013. Khasiat Umbi Bawang Dayak (Eleutherine palmifolia (L) Merr) Sebagai Herbal Antimikroba Kulit.Kartika: Jurnal IImiahFarmasi, 1(1):31-37.

4. Syamsul, E.S., Supomo, Wijaya, H., Nugroho, B.A. 2015. Ethanolic Extract Formulation of Bawang Tiwai (Eleutherine Americana) in Antiacne Cream.Majalah Obat Tradisional, 20(3):149-157.

5. Galingging, R. Y., 2009. Bawang Dayak Sebagai Tanaman Obat Multifungsi. Warta Penelitian dan Pengembangan Vol. 15: Kalimantan Tengah.

6. Sim dan Romi. 2009. Kejadian infeksi luka episitomi dan pola bakteri pada persalinan normal di RSUD H. Adam Malik dan RSUD dr. Pirngadi Medan. Tesis Universitas Sumatera Utara: Medan. 
Susi Novaryatiin, Ahmad Ramli dan Syahrida Dian Ardhany

7. Departemen Kesehatan Republik Indonesia. 1995. Materia Medika Indonesia Jilid IV. Jakarta.

8. Murugan, M. dan Kolanjinathan, K. 2016. Qualitative Phytochemical Screening and Antioxidant Activity of Elytraria acaulis Lindau (Acanthaceae). Asian Journal of Pharmaceuticaland Clinical Research, 9(Suppl.3):1-4.

9. Arifianti, L., Oktarina, R.D., Kusumawati, I. 2014. Pengaruh Jenis Pelarut Pengekstraksi Terhadap Kadar Sinesetin dalam Ekstrak Daun Orthosiphon stamineus Benth. Planta Husada:Jurnal Penelitian Tanaman Obat Indonesia, 2(1):3.

10. Clinical Laboratory Standart Institute. 2013. Performance Standart for Antimicrobial Susceptibility Testing; Twentieth Information Supplement. USA.

11. Putra, R.E.D., Homenta, H., Wowor, V.N.S. 2017. Uji Daya Hambat Perasan Jeruk Purut Citrus hytrix Terhadap Bakteri Staphylocuccus aureus Secara In Vitro.Pharmacon, 6(1):65-66.

12. Tjay. T. H., dan Rahardja. K. 2007. Obat-Obat Penting. Elex Media Komputerindo: Jakarta.

13. Pan, X., Chen., Wu, T., Tang, H., and Zhao, Z. 2009. The Acid, Bile Tolerance and Antimicrobial Property of Lactobacillus acidophilus NIT. J. Food Control.

14. Ningsih, D.R., Zusfahair, Z., Kartika, D. 2016. Identification of Secondary Metabolites Compounds and Antibacterial Activities on The Extract of Soursop Leaf. Molekul: Jurnal IImiah Kimia, 11(1):101-111.

15. Permatasari, G.A.A.A., Besung, I.N.K., Mahatmi, H. 2013. Daya Hambat Perasan Daun Sirsak Terhadap Pertumbuhan Bakteri Escherichia coli.Jurnal Medicus Veterinus, 2(2):162169.

16. Sulastrianah, S., Imran, I., Fitria, E.S. 2014. Uji Daya Hambat Ekstrak Daun Sirsak (Annona muricata L) dan Daun Sirih (Piper betle L) Terhadap Pertumbuhan Bakteri Escherichia Coli.MEDULA: Jurnal IImiah FakultasKedokteran Universitas Halu Oleo, 1(2):76-84.

17. Hafizah, I., Muliati, F.F., Sulastrianah. 2016. Aktivitas Antibakteri Ekstrak
Etanol Porifera (Spongia officinalis) Terhadap Staphylococcus aureus ATCC 25923.MEDULA: Jurnal IImiah FakultasKedokteran Universitas Halu Oleo, 4(1):296-302. 